\title{
Aspek Fisiologik Short Chain Fatty Acid (SCFA)
}

\author{
William S. Wangko
}

\author{
Rumah Sakit Gereja Masehi Injili di Minahasa Pancaran Kasih Manado, Sulawesi Utara, \\ Indonesia \\ Email: william.wangko06@gmail.com
}

\begin{abstract}
Consumption of fiber-rich diet and undigested carbohydrate is very beneficial in the maintance of optimal health and control of metabolic and cardiovascular diseases. Short chain fatty acid (SCFA) is an end-product of carbohydrate and protein fermented by gut microbiota. There are three main SCFAs, as follows: acetate, propionate, and butyrate. Acetate and propionate are mainly synthezised by Bacteroidetes meanwhile butyrate by Firmicutes. Physiological aspects of SCFA are inter alia maintenance of homeostasis, modulation of metabolic process and immune system, and direct protection against pathogens in varied body tissues including intra and extra intestinal tissues. The physiological aspects of SCFAs are very promising, albeit, their implementation in therapy is still very limited. There are still challenges in translation the SCFAs' effects from animal model to human being due to differences in physiological processes and diet, as well as implementation of a certain amount of SCFA to the target tissue/organ.
\end{abstract}

Keywords: short chain fatty acid (SCFA), functions of SCFA, gut microbiota

\begin{abstract}
Abstrak: Dewasa ini telah diketahui bahwa konsumsi diet berserat dan karbohidrat yang tak tercerna sangat bermanfaat dalam mempertahankan status kesehatan yang optimal dan mengatasi berbagai penyakit metabolik dan kardiovaskular. Short chain fatty acid (SCFA) merupakan produk akhir hasil fermentasi karbohidrat dan protein oleh mikrobiota usus. Terdapat tiga jenis SCFA yang utama pada manusia yaitu asetat, propionat, dan butirat. Mikrobiota Bacteroidetes terutama menyintesis asetat dan propionat sedangkan Firmicutes terutama menyintesis butirat. Aspek fisiologik SCFA yaitu antara lain mempertahankan homeostasis tubuh. memodulasi proses metabolism dan sistem imun, serta memroteksi secara langsung terhadap patogen pada berbagai jaringan tubuh termasuk jaringan intra dan ekstraintestinal. Walaupun efek fisiologik SCFA sangat menjanjikan namun pemanfaatannya dalam pengobatan masih sangat terbatas. Hal ini disebabkan oleh karena adanya tantangan dalam mentranslasi efek SCFA dari hewan model ke manusia yang disebabkan perbedaan fisiologik dan diet, serta cara memasok sejumlah SCFA yg cukup ke jaringan/organ target.
\end{abstract}

Kata kunci: short chain fatty acid (SCFA), fungsi SCFA, mikrobiota usus

\section{Pendahuluan}

Secara global telah terjadi perubahan pola makan dari diet kaya lemak sehat dan serat ke arah diet kaya lemak jenuh dan karbohidrat terutama pada masyarakat perkotaan. ${ }^{1}$ Hal ini tertuang dalam prevalensi obesitas yang telah meningkat di seluruh dunia dalam 50 tahun terakhir. ${ }^{2}$ Seperti halnya diabetes melitus dan penyakit kardiovaskular, obesitas juga merupakan suatu kondisi inflamasi kronis gradasi rendah (low-grade) disertai adanya disfungsi keseimbangan energi. ${ }^{1,3}$ Selain itu, obesitas meningkatkan risiko berbagai penyakit, termasuk diabetes melitus, hipertensi, infark miokard, perlemakan hati, stroke, demensia, osteoartritis, obstructive sleep apnoea, dan kanker. ${ }^{2,3}$ Saeedi et al $^{4}$ mengemukakan bahwa hampir setengah biliun penduduk di seluruh dunia menyandang diabetes, dan angka ini diproyeksikan akan meningkat sebesar 25\% di tahun 2030 dan 51\% di tahun 
2045. Demikian pula Alexander ${ }^{5}$ melaporkan secara global $26 \%$ penduduk dunia (972 juta) menyandang hipertensi, dan prevalensi ini diperkirakan akan meningkat sampai $29 \%$ di tahun 2025. Hipertensi merupakan kontributor utama untuk penyakit jantung dan stroke yang merupakan penyebab kematian pertama dan ketiga di seluruh dunia.

Obesitas juga berhubungan langsung dengan inflamasi patologik lainnya seperti asma, kolitis, dan beberapa jenis keganasan termasuk kanker kolon. Hal-hal tersebut menarik perhatian para peneliti untuk menelusuri metabolit yang berperan dan aspek fisiologiknya baik pada keadaan sehat maupun patologik, termasuk hubungan metabolit tersebut dengan sistem imun. ${ }^{1,6}$

Short chain fatty acid (SCFA) adalah asam organik rantai pendek yang disintesis oleh mikrobiota usus melalui fermentasi sebagian besar karbohidrat yang tak tercerna dan sebagian kecil oleh protein diet dan endogen. ${ }^{7,8}$ Short chain fatty acid telah diketahui merupakan produk akhir utama (major end-product) fermentasi mikrobiota usus dalam kolon dan usus halus dital dan memiliki berbagai peran terhadap fisiologi manusia. ${ }^{9}$ Berbagai studi pre-klinik menyokong peran SCFA sebagai modulator fungsi saluran cerna maupun pada proses inflamasi, metabolik, dan autoimun. Studi epidemiologi turut menunjang adanya hubungan antara konsumsi serat dalam diet dan turunnya risiko penyakit kardiovaskular, diabetes, dan kanker kolon. Penelitian terutama pada hewan model memperlihatkan bahwa SCFA memengaruhi luaran kesehatan dan berbagai jenis penyakit. Namun translasi efek SCFA dari hewan model ke manusia masih sangat terbatas karena adanya perbedaan fisiologik dan jenis diet. Selain itu, yang turut menjadi tantangan ialah bagaimana memasok sejumlah SCFA yang cukup ke tempat target baik saluran cerna maupun sistem sirkulasi. ${ }^{10}$

Pada dekade terakhir ini SCFAs telah mendapat banyak perhatian karena efek fisologik dan farmakologiknya, serta hubungan diet kaya serat dengan risiko penyakit kardiovaskular, diabetes, dan kanker kolon. ${ }^{11}$ Telaah ini bertujuan untuk menelu- suri aspek fisiologik dari SCFA dan diharapkan agar dapat memberi wawasan yang lebih luas untuk penelitian di masa depan.

\section{Mikrobiota Usus}

Salah satu permukaan terbesar dalam tubuh manusia yang memerantarai pejamu, lingkungan, dan antigen ialah saluran cerna yang mencakup luas sekitar 250-400 $\mathrm{m}^{2}$. Selama rerata masa hidup, sekitar 60 ton makanan melalui saluaran cerna disertai dengan mikroorganisme berasal dari lingkungan luar yang dapat mengancam integritas usus. ${ }^{12}$

Saluran cerna dihuni oleh kelompok mikroorganisme yang besar dan sangat bervariasi, terdiri dari bakteri, archaea, protozoa, eukarya, dan virus; keseluruhannya disebut mikrobiota usus yang telah berevolusi bersama pejamu selama beriburibu tahun dan membentuk suatu kerjasama yang mutualistik. Jumlah mikrobiota saluran cerna dapat melampaui $10^{14}$ yang diperkirakan lebih dari 10x lipat jumlah sel tubuh manusia, dan 100x jumlah kandungan genomik manusia. ${ }^{11-15}$ Menurut data Metahit dan Human microbiome project telah teridentifikasi 2172 spesies terdiri dari 12 phyla; 93,5\% terdiri dari Proteobacteria, Firmicutes, Actinobacteria, dan Bacteroidetes. ${ }^{16.17}$ Pada manusia terdapat 386 spesies yang absolut anaerobik dan ditemukan pada mukosa seperti rongga mulut dan saluran cerna. $^{16}$

Mikrobiota yang diperoleh setelah kelahiran biasanya menetap sepanjang hidup dengan dipengaruhi oleh regulasi geospasial. ${ }^{18,19}$ Pada individu dewasa, mikrobiota umumnya didominasi oleh Firmicutes dan Bacteriodetes sedangkan Actinobacteria, Proteobacteria, and Verrucomicrobia juga cukup sering ditemukan walaupun dalam jumlah kecil. ${ }^{15}$ Lambung, duodenum, dan jejunum proksimal terutama dihuni oleh mikrobiota aerobik termasuk Streptococci spp. dan Lactobacilli spp. sedangkan ileum distal lebih banyak dihuni oleh mikrobiota anerobik yang menyerupai penghuni kolon yaitu Bacteroidetes, Bifidobacterium, dan Clostridium spp. ${ }^{18,19}$ Bacteroidetes terutama menyintesis asetat dan propionat sedang- 
kan Firmicutes terutama menyintesis butirat. ${ }^{11}$ Beban mikrobiota terbanyak ialah dalam kolon. Walaupun jumlah mikrobiota lebih sedikit ditemukan dalam usus halus namun jumlah spesiesnya lebih banyak. ${ }^{20}$

Mikrobiota memiliki molekul pengikat karbohidrat (carbohydrate-binding molecules) dan berbagai enzim termasuk glikosida hidrolase, glikosiltransferase, polisakarida hidrolase, dan esterase karbohidrat yang dapat melakukan hidrolisis berbagai serat makanan. ${ }^{21}$ Dengan demikian, mikrobiota usus dapat memroses produk makanan yang tidak dapat dicerna dalam saluran cerna manusia menjadi berbagai metabolit, antara lain SCFA. ${ }^{20}$

Mikrobiota usus sangat dipengaruhi oleh berbagai faktor, antara lain genetik, fisiologi pejamu (usia, penyakit penyerta, stress, dll), pola hidup, faktor lingkungan, pemakaian obat-obatan, dan diet. Perubahan pada mikrobiota usus baik komposisi maupun metabolismenya dapat memengaruhi respons imun dan homeostasis tubuh. 11,13,18,20,21 Studi epidemiologi memperlihatkan hubungan perubahan komunitas mikrobiota dengan kepekaan terhadap alergi, misalnya turunnya diversitas mikrobiota usus selama masa infant dapat meningkatkan perkembangan penyakit asma. Demikian pula penggunaan antibiotik dapat disertai predisposisi penyakit alergi saluran napas. ${ }^{13,18}$ Melalui 16S rRNA dan metagenomic sequencing diestimasi saluran cerna yang sehat didominasi oleh bakteri phyla Firmicutes dan Bacteroidetes. ${ }^{13}$

\section{Short chain fatty acids (SCFA)}

Mikrobiota usus telah mengembangkan hubungan mutalistik simbiotik dengan pejamunya. ${ }^{22}$ Enzim usus manusia hanya dapat mencerna sebagian kecil karbohidrat dalam diet melalui kerja amilase pankreas dan saliva, serta disakaridase, sukrase, dan laktase pada brush border enterosit namun enzim-enzim tersebut tidak dapat mencerna sebagian besar karbohidrat kompleks dan polisakarida yang berasal dari tumbuhan. ${ }^{10,11,21}$ Berbeda halnya dengan mikrobiota usus yang dapat mengekspresikan enzim aktif terhadap fermentasi karbohidrat untuk menghasilkan metabolit (antara lain SCFA) seperti propionat koA transferase dan propionataldehida dehidrase. ${ }^{10-12}$ Demikian pula karbohidrat kompleks dan polisakarida juga dapat dimetablolisir olah mikrobiota usus untuk menghasilkan metabolit, ${ }^{21}$ yang meliputi SCFA (terutama), derivat indol, poliamin, asam organik, dan vitamin. $^{11}$ Postler dan Ghosh ${ }^{23}$ membagi metabolit menjadi tiga jenis, yaitu metabolit yang diproduksi oleh mikrobiota usus dari obatobatan atau komponen diet, metabolit yang diproduksi oleh pejamu dan dimodifikasi oleh mikrobiota usus, dan metabolit yang disintesis de novo oleh mikrobiota usus.

Short chain fatty acid adalah golongan asam organik lemah dengan jumlah ion karbon sebanyak 1-6. , $8,10,11,24,25$ SCFA terutama diproduksi oleh mikrobiota usus dalam kolon dan distal usus halus melalui fermentasi karbohidrat (khususnya resistant starch dan serat makanan) dan dalam jumlah lebih kecil protein. Karbohidrat yang dicerna dapat berasal dari makanan maupun endogen, demikian pula halnya dengan protein. ${ }^{7,8,10,11,24,25}$ Jenis SCFA yang terbanyak ditemukan pada manusia ialah asetat (C2), propionat (C3), dan butirat (C4) yang mencapai $\geq 95 \%$ dari total SCFA; sisanya ialah antara lain format, valerat, isovalerat, isobutirat, kaproat, dan isokaproat. ${ }^{10,11,19,26-}$ 28 Asetat diproduksi oleh sebagian besar mikrobiota usus sedangkan propionat dan butirat oleh subset bakteri usus yang berbeda melalui jalur molekular. Butirat diproduksi dari karbohidrat melalui glikolisis dan asetil-koA sedangkan 2 jalur lain yaitu suksinat atau propanodiol untuk pembentukan propionat tergantung dari jenis bahan dasar karbohidrat. . $^{11,12,28}$

Mayoritas SCFA akan diabsorpsi oleh enterosit dan dipergunakan sebagai sumber energi tetapi sebagian akan dilepaskan melalui membran basolateral ke vena porta dan mencapai sirklulasi sistemik. ${ }^{25}$ Selain itu, SCFA yang telah diabsorpsi akan terlibat dalam regulasi proses intrasel seperti ekspresi gen, kemotaksis, diferensiasi, proliferasi, dan apoptosis. ${ }^{11,12,28}$

Rasio konsentrasi SCFA dalam lumen kolon ialah $60 \%$ asetat, $25 \%$ propionat, dan 
$15 \%$ butirat. $^{7,8,10,24,25}$ Rasio molar dan kandungan SCFA di dalam kolon dipengaruhi oleh beberapa faktor, termasuk strain dan jumlah mikrobiota usus, sumber substrat, genotip pejamu, dan waktu transit usus.11,12,28 Dengan meningkatnya produk yang bersifat asam maka $\mathrm{pH}$ lumen kolon proksimal menjadi lebih rendah yang dapat memengaruhi pertumbuhan mikroba patogen seperti Escherichia coli dan Salmonella spp. ${ }^{7,8,10,24,25}$ Tampaknya mikrobiota lebih menyenangi fermentasi karbohidrat daripada protein sehingga konsentrasi SCFA dijumpai tertinggi di kolon proksimal dimana sebagian besar substrat untuk fermentasi tersedia, dan berkurang kearah kolon distal. ${ }^{8}$ Pada kasus sudden death didapatkan bahwa konsentrasi SCFA tertinggi pada kolon proksimal yaitu 69, 25, dan $25 \mathrm{mMol} / \mathrm{L}$ untuk asetat, propionat, dan butirat secara berurut. Konsentrasi yang tinggi dari SCFA merefleksikan $\mathrm{pH}$ rendah dalam kolon asenden yang sangat berbeda dengan $\mathrm{pH}$ tinggi dan konsentrasi SCFA rendah dalam feses. ${ }^{10}$

\section{Produksi SCFA}

Short chain fatty acid terutama diproduksi oleh mikrobiota usus dalam kolon melalui fermentasi karbohidrat yang berasal dari tumbuhan dan juga protein atau peptida yang lolos dari pencernaan dan absorpsi di usus halus. ${ }^{11}$ Produksi SCFA oleh mikrobiota usus sangat berperan terhadap kesehatan namun sangat dipengaruhi oleh jumlah dan jenis serat makanan yang dapat difermentasi. ${ }^{9}$ Baxter et $\mathrm{al}^{9}$ melaporkan bahwa serat yang dapat difermentasi tidak seluruhnya mempunyai kemampuan yang sama dalam menstimulasi produksi SCFA. Selain itu, komposisi mikrobiota individu turut menentukan apakah mikrobiota tersebut akan berespon terhadap suplemen makanan tertentu.

Fermentasi mikrobiota terhadap serat diet yang tidak diserap dalam usus halus tetapi dilanjutkan ke kolon akan menghasilkan metabolit antara lain SCFA. Terdapat tiga jenis SCFA utama yaitu butirat, asetat, dan propionat. Asetat merupakan SCFA yang terbanyak diproduksi disusul oleh propionat dan butirat dengan rasio molar $3: 1: 1 .^{11,22}$

Tubuh manusia tidak dapat memroduksi enzim yang mengkatalisis fermentasi karbohidrat sedangkan mikrobiota usus dapat menghasilkan sejumlah enizm untuk memetabolisir karbohidrat menjadi SCFA. Umumnya mikrobiota menyintesis asetat yang berasal dari asetil-koA atau alternatifnya dengan menggunakan format, hidrogen, dan karbon dioksida melalui jalur Wood-Ljungdahl. ${ }^{22}$ Produksi propionat umumnya melalui jalur suksinat, yang memerlukan heksosa dan pentose yang didominasi oleh filum Bacteroidetes. Selain itu, propionat juga dapat diproduksi oleh spesies Veilonella dengan menggunakan laktat melalui jalur akrilat atau jalur propanediol pada Roseburia dan Ruminococcus yang menggunakan fukose dan rhamnose. Berbeda halnya dengan butirat yang terutama diproduksi melalui kondensasi grup thio dari koenzim-A dengan group karboksi dari asetil-koA yang menghasilkan butiril-koA yang selanjutnya dikonversi menjadi butirat. Filum Firmicutes merupakan spesies utama yang menyintesis butirat di dalam kolon. ${ }^{11,22}$

Protein atau peptida diet yang mengandung asam lemak bercabang dapat dimetabolisir menjadi SCFA antara lain sebagai 2metilbutirat, isobutirat, dan isovalerat. ${ }^{11}$

\section{Transpor SCFA}

Short chain fatty acid diabsorpsi pada setiap segmen usus yang dibuktikan melalui percobaan pada hewan dan manusia. ${ }^{7}$ Absorpsi SCFA di kolon terjadi melalui tiga mekanisme, yaitu: difusi pasif, elekroneural, dan elektrogenik. Muatan SCFA menentukan jenis mekanisme absorpsinya. Difusi pasif SCFA terutama bila SCFA dalam pentuk proton dan merupakan mekanisme transpor utama pada $\mathrm{pH}$ fisiologik. Berbeda halnya dengan SCFA dalam bentuk anion yang tergantung pada carrier-mediated uptake yang terjadi melalui empat transporter utama, yaitu monocarboxylate transporter 1 (MCT1) dan MCT4 sebagai transporter elektroneutral yang memerlukan hidrogen, dan sodium coupled monocarbo- 
xylate transport 1 (SMCT1) dan SCMT2 yang mengandalkan sodium dan elektrogenik, serta elektroneutral secara berurut. ${ }^{7,11}$

Oleh karena SCFA terutama butirat memasok $80 \%$ energi kolonosit per hari maka butirat tidak ditemukan dalam jumlah besar dalam darah portal. Berbeda halnya dengan asetat dan propionat yang sebagian besar diambil oleh kolonosit dan ditranspor ke vena portal untuk metabolime jaringan perifef antara lain jaringan otot. ${ }^{7,11}$ Selain itu, sebagian besar propionat dimetabolisir di dalam tubuh sehingga asetat merupakan SCFA terbesar dalam sirkulasi sistemik. Sekum dan kolon mengabsorpsi secara cepat dan efisien SCFA yang dihasilkan oleh kolonosit, dan hanya tersisa 5\% SCFA yang diekskresikan melalui feses. ${ }^{11}$

\section{Mekanisme kerja SCFA}

Efek SCFA di dalam usus dan di tempat lainnya berdasarkan kemampuannya menstimulasi tiga jenis G-protein coupled receptors (GPRs), yaitu: GPR41, GPR43, dan GPR109a. GPR41 terekspresi pada banyak jenis sel dan jaringan terutama pada monosit darah tepi, monosit jaringan perifer, sel dendritik, dan neutrofil polimorfonuklear (PMN) serta di limpa, limfonodus, sumsum tulang, usus halus, dan jaringan lemak. Afinitas tertinggi dari GPR 41 ialah terhadap propionat, diikuti oleh butirat dan asetat. Ekspresi GPR43 lebih terbatas, yaitu terutama di usus dan populasi imun spesifik seperti PMN, monosit perifer, dan limfosit. Afinitasnya terhadap SCFA yang tertinggi pada propionat, diikuti oleh asetat dan butirat. Berbeda halnya dengan GPR 109a yang hanya berikatan dengan butirat dan terekspresi di usus, makrofag, monosit, PMN, sel dendritik, adiposit, dan sel Langerhans. ${ }^{3,6,13,22,26,27,29}$

SCFA juga bekerja sebagai histone deacetylase inhibitor (HDACi) kuat (secara berurut butirat>propionate>asetat) yang berperan dalam memodulasi stabilitas dan aktivasi protein melalui asetilasi. ${ }^{13,22,26}$

\section{Aspek Fisiologik SCFA}

Tubuh manusia dan mikrobiota usus bersama-sama memroduksi serangkaian metabolit yang berkerja dengan saling berinteraksi. ${ }^{11}$ Berbagai studi telah menunjukkan bahwa mikrobiota usus melalui metabolitnya yaitu SCFA berfungsi antara lain mempertahankan homeostasis tubuh. memodulasi proses metabolisme dan sistem imun, serta proteksi langsung terhadap patogen. ${ }^{11,21,22}$

\section{Fungsi SCFA intraintestinal}

SCFA terutama butirat merupakan sumber energi kolonosit, ${ }^{7,12,18,28,29}$ dan diperkirakan memasok 60-80\% energi yang dibutuhkan sel-sel tersebut dan 5-15\% dari kalori total kebutuhan manusia. ${ }^{8,12,20,26}$

Secara fisiologik, untuk mempertahankan homeostasis hubungan mikrobiota usus dan pejamu maka kontak langsung antara sel epital dan mikrobiota yang berkolonisasi diminimalkan dengan berbagai mekanisme pertahanan termasuk produksi musin, sekresi imunoglobulin A, dan peptida antimikrobial. Short chain fatty acid dapat memodulasi berbagai aspek mekanisme pertahanan melalui imunitas mukosa, antara lain meningkatkan diferensiasi dan produksi musin oleh sel goblet, serta permeabilitas taut sekap. ${ }^{13,28}$ Produksi musin juga berperan sebagai penyekat antara lingkungan eksternal dan sel epitel usus. ${ }^{11,22}$ Pengaturan sintesis musin oleh SCFA sangat penting agar pejamu dapat meningkatkan kolonisasi bakteri yang bermanfaat sehingga dapat berkompetisi dengan bakteri patogen. $^{22}$ Hatayama et $\mathrm{al}^{30}$ melaporkan bahwa butirat menstimulasi ekspresi musin (MUC2) pada sel epitel kolon yang menyerupai sel goblet LS174T. MUC2 nerupakan musin utama yang menyusun lapisan mukus kolon. Jung et $\mathrm{al}^{31}$ mendapatkan bahwa butirat juga meningkatkan ekspresi MUC 3, 4, dan 12 sambil meningkatkan adherensi lactobacillus dan menurunkan adherensi Escherichia coli in vitro. SCFA dapat memberi sinyal melalui PR43 dan GPR109A pada sel epitel usus untuk menginduksi aktivasi NLRP3 inflamasom yang berperan penting dalam mekanisme pertahanan dan perbaikan kehidupan sel, serta mencegah terjadinya dextran sulfate sodium (DSS) induced colitis. ${ }^{13}$ Selain itu, SCFA mening- 
katkan produksi IgA usus melalui peningkatan metabolisme sel plasma, ${ }^{22}$ serta memodulasi sistem imun intraepitelial dan lamina propria usus untuk meregulasi homeostasis pejamu terhadap mikroba. ${ }^{11,22}$ Dalam usus besar, sel epitel dapat menyekresi peptida antimikrobial (antimicrobial peptides/AMPs) yang penting sebagai pertahanan terhadap perlekatan dan invasi baik dari patogen internal maupun eksternal. Proses ini disertai induksi produksi Il-37. SCFA dapat menstimulasi AMPs yang berperan sebagai pertahanan imunitas awal (innate) terhadap patogen yang berfungsi sebagai pertahanan lini pertama dari sel epitel usus. $^{11,22}$

Short chain fatty acid berperan mengatur respons inflamasi serta merangsang produksi sitokin misalnya Il-18 yang terlibat dalam mempertahankan dan memperbaiki integritas epitel. ${ }^{28}$ SCFA juga mengatur turnover lapisan epitel saluran cerna, meregulasi proliferasi sel punca, dan memelihata taut sekap. ${ }^{11,14,22}$ Selain itu, SCFA dapat mempertahankan integritas barrier epitel melalui regulasi protein taut sekap yaitu claudin-1, occuldin dan zonila occuldens-1. Penurunan kadar protein-protein ini dapat memfasilitasi translokasi bakteri dan lipopolisakarida yang memicu terjadinya reaksi inflamasi. SCFA dapat meningkatkan pengaturan membran sel, migrasi sel mukosa, serta proliferasi dan diferensiasi kolonosit. ${ }^{11}$

Short chain fatty acid dalam usus menurunkan $\mathrm{pH}$ luminal yang mereduksi pertumbuhan mikroorganisme patogen. Produksi asetat oleh Bifidobacteria telah diteliti dapat menghambat pertumbuhan enteropatogen pada tikus. Penelitian in vivo dan in vitro mengindikasikan kadar butirat yang tinggi menyebabkan peningkatan produksi musin yang mereduksi adhesi bakteri dan memperbaiki integritas epitel. ${ }^{28}$

Studi pada tikus memperlihatkan bahwa produksi butirat menyebabkan peningkatan jumlah sel Treg. Studi in vitro melaporkan bahwa butirat meregulasi forkhead transcription factor FOXP3, berkerja sebagai inhibitor histon deasetilase (HDACi) dan promosi asetilasi histon $\mathrm{H} 3$ pada promotor enkoding gen FOXP3. SCFA juga merangsang perkembangan sel dendritik dan sitokin inflamasi, dan oleh karenanya meregulasi makrofag intestinal. Berbagai peran SCFA dalam energi dan metabolism menyokong aktivasi/diferensiasi sel B dan produksi antibodi (IgM/IgG). ${ }^{11}$

Penelitian pada tikus secara in vivo dan in vitro menunjukkan bahwa butirat dan propionat dapat menginduksi produksi hormon oleh bakteri usus. ${ }^{28}$

Turunnya gradien butirat dari lumen ke kripta diduga untuk mengontrol turnover sel epitel usus dan homeostasis dengan memromosikan proliferasi sel epitel kolon pada dasar kripta serta meningkatkan apoptosis dan eksfoliasi sel dekat lumen. Butirat dapat melemahkan translokasi bakteri dan meningkatkan fungsi barier usus dengan mengatur taut sekap dan sintesis musin. ${ }^{12}$

Secara langsung, SCFA dapat memengaruhi komposisi mikrobiota. SCFA dapat menjadi sumber karbon bagi mikrobiota tetapi di sisi lain pada konsentrasi tinggi dapat bersifat toksik terhadap beberapa spesies mikrobiota. SCFA yang tidak terionisasi dapat berdifusi melalui membran bakteri dan menyebabkan rentetan variasi keseimbangan osmotik, sintesis DNA, uptake asam amino, dan metabolism oksidatif ke respons kemotaksis. Sebagai contoh, pada konsentrasi tinggi dan $\mathrm{pH}$ rendah, SCFA dapat menghambat secara kuat pertumbuhan Salmonella melalui reduksi ekspresi gen invasif. ${ }^{11,26}$

Dengan menurunkan $\mathrm{pH}$ luminal SCFA dapat meningkatkan absorpsi beberapa jenis nutrien. ${ }^{32}$ Beberapa studi menyatakan bahwa peningkatan absorpsi mineral berhubungan dengan meningkatnya taxa mikrobiota tertentu dan menurunnya $\mathrm{pH}$ feses yang menyokong akibat langsung produksi SCFA. SCFA juga dapat menginduksi ekspresi retinal-dehyde dehydrogenase (RALDH1) yaitu enzim yang mengonversi vitamin A dalam sel epitel usus halus baik secara in vivo maupun in vitro. ${ }^{20}$

\section{Fungsi SCFA ekstraintestinal}

Baik secara lokal maupun perifer SCFA sangat berperan dalam mengembangkan 
fungsi pleiotrofiknya pada berbagai sel yang meliputi pemeliharaan dan perbaikan integritas epitel sampai ke penghambatan inflamasi pada usus dan saluran napas. Mekanisme yang menghubungkan SCFA dari usus dan paru masih belum jelas namun dengan kemampuan pleiotrofiknya dapat dipahami bahwa SCFA baik secara langsung maupun tidak langsung dapat memengaruhi fungsi berbagai sel dan jaringan termasuk sel-sel epitel serta sel imun innate dan adaptif. ${ }^{13,24,27}$

Fungsi proteksi SCFA telah banyak dipelajari pada hewan coba. Efek antiinflamasi dan kerja imunomodulator juga ditemukan di daerah perifer terutama sepanjang gut-lung axis. Seperti halnya dengan efek intraintestinal, SCFA juga dapat menghasilkan kelompok sel Treg perifer ekstratimik terkait penyakit alergi saluran napas melalui inhibisi HDAC. ${ }^{13}$

Short chain fatty acid yang bersirkulasi tidak terakumulasi dalam jaringan paru, dan bakteri dalam paru tidak memroduksi SCFA. Asetat dan propionat dalam sirkulasi dapat memodulasi hematopoiesis dan fungsi sel dendritik dalam sumsum tulang pada inflamasi saluran napas yang dimediasi oleh Th2. Metabolit ini dapat meningkatkan pembentukan makrofag dan progenitor sel dendritik. Data penelitian menyokong bahwa melalui gut-lung axis, SCFA memudahkan sel mieloid sumsum tulang bermigrasi ke paru dan membentuk mileu antiinflamasi. ${ }^{13}$

Short chain fatty acid memromosikan rekrutmen dan maturasi sel-sel imun yang berfungsi proteksi terhadap respons inflamasi. SCFA merangsang aktivitas metabolik pejamu melalui perannya sebagai jembatan antara diet berserat, mikrobiota komensal, dan pejamu. SCFA yang diproduksi dalam usus didistribusikan secara sistemik dan dipergunakan sebagai penghasil energi atau molekul pesinyal. ${ }^{28}$ Cait et $\mathrm{al}^{24}$ menyatakan bahwa SCFA memodulasi respons imun sistemik dengan penekanan respons Th2 melalui efek langsung pada sel $\mathrm{T}$ dan sel dendritik.

Theiler et $\mathrm{al}^{27}$ melaporkan bahwa SCFA dapat melemahkan eosinofil dalam beberapa hal, yaitu: adhesi ke endotel, migrasi, dan survival; kesemuanya ini tidak tergantung pada GRP41 dan GRP43 tetapi disertai dengan asetilasi histon. Secara in vivo, butirat memperbaiki saluran napas yang diinduksi alergen dan eosinofilia paru, menurunkan kadar sitokin tipe 2 dalam cairan bronkial, dan memperbaiki hiperresponsif saluran napas pada tikus. ${ }^{27}$ SCFA terutama butirat dapat meningkatkan aktivitas anti-inflamasi melalui kerja terhadap migrasi sel imun, adhesi, ekspresi sitokin, dan efek terhadap proses selular (proliferasi, aktivasi, dan apoptosis). ${ }^{3}$

Wangko $^{33}$ meneliti hubungan antara SCFA butirat dengan tes kontrol asma (TKA), IgE total, dan arus puncak ekspirasi (APE) dan mendapatkan hubungan linear positif antara SCFA butirat dengan TKA dan APE serta hubungan linear negatif dengan IgE total. Pada subyek normal didapatkan hubungan linear positif antara SCFA butirat dengan APE dan hubungan linear negatif pada IgE total, namun tidak didapatkan perbedaan bermakna pada nilai SCFA butirat. Hal ini dapat disebabkan karena jumlah sampel yang terbatas yaitu 16 pengidap asma dan 19 subyek normal.

Short chain fatty acid dapat meregulasi lipid hati dan homeostasis glukosa melalui mekanisme yang kompleks. Di dalam hati, propionat dapat mengaktivasi glukoneogenesis sedangkan asetat dan butirat bersifat lipogenik. Butirat dan propionat merupakan HDACi yang secara epigenetik mengatur ekspresi gen. SCFA juga memodulasi nafsu makan dan asupan energi melalui mekanisme yang dimediasi oleh reseptor. Propionat berperan dalam mengatur sel beta pankreas dan mengurangi kebiasaan makan melalui jalur striata. ${ }^{28}$ SCFA dapat menstimulasi skeresi inkretin, menghambat oksidasi asam lemak dan sintesis kolesterol, dan mengaktifkan GPR 40-43. ${ }^{18}$

Mikrobiota usus telah dilaporkan dapat memromosi hematopoiesis progenitor mieloid dalam limpa namun efek SCFA terhadap hematopoiesis ekstramedular masih perlu ditelusuri lebih lanjut. ${ }^{13}$ 
Beberapa penyakit/gangguan yang berhubungan dengan mikrobiota usus dan SCFA

Dengan kemajuan teknologi dalam memperoleh gambaran dan karakteristik yang kompleks dari ekosistem maka peran mikrobiota pada berbagai penyakit intra dan ekstrainterstinal telah menjadi lebih jelas. Manfaat mikrobiota usus terhadap pejamu melalui berbagai fungsi fisiologik antara lain menguatkan integritas usus (shaping), menghasilkan energi, proteksi terhadap patogen, dan mengatur imunitas pejamu. Kelangsungan mekanisme ini dapat terganggu bila terjadi perubahan komposisi mikrobiota yang dikenal sebagai disbiosis. ${ }^{12}$

Telah terdata bahwa mood dan perilaku juga turut berperan dalam hal perubahan komposisi dan fungsi mikrobiota usus. ${ }^{23}$

Mikrobiota usus juga memengaruhi hematopoiesis di sumsum tulang dalam hal memromosi steady-state myelopoiesis namun hal ini masih memerlukan studi lanjut mengenai mekanisme dasar untuk memodulasi sistem imun yang merupakan dasar tujuan pengobatan. ${ }^{13}$

Saluran cerna manusia ditempati oleh berbagai mikrobiota yang sangat mutualistik. ${ }^{23}$ SCFA dapat memroteksi epitel kolon melalui peningkatan ekspresi musin 2, serta modulasi stres oksidatif dan respons imun. Disbiosis dapat disertai oleh gangguan patologik yang serius pada pejamu termasuk penyakit metabolik, kanker kolorektal, dan inflammatory bowel disease seperti penyakit Crohn dan kolitis ulseratif. ${ }^{11,23}$

Sebagian besar SCFA yang diproduksi dalam usus digunakan sebagai sumber energi dan dapat menghasilkan sebesar 5$15 \%$ dari kebutuhan kalori per hari; hal ini mengasumsikan adanya hubungan SCFA dengan gangguan metabolik seperti obesitas dan DM. ${ }^{28}$

Dalam keadaan sehat, SCFA berperan sebagai regulator kunci untuk memodulasi integritas usus, nafsu makan, homeostasis energi, produksi hormon usus, dan fungsi imun. Dalam keadaan sakit, SCFA dapat menampilkan berbagai efek protektif terhadap obesitas, diabetes, kolitis ulseratif, proktitis akibat radiasi, penyakit Crohn, kanker kolorektal, Parkinson, asma, dan lainnya. Hal ini disebabkan karena SCFA mepunyai efek anti inflamasi pada saluran cerna dan jaringan lainnya yang dapat menekan perkembangan berbagai penyakit inflamasi. ${ }^{11}$ Telah diketahui bahwa SCFA berikatan dengan reseptor G-protein ( $G$ protein coupled receptors, GPCRs) dan memicu jalur sinyaling yang berefek antiinflamasi pada respons imun pejamu. ${ }^{28}$

Yuan et $\mathrm{al}^{25}$ menyatakan bahwa SCFA memiliki efek berbeda terhadap aktivasi inflamasom Nlrp3 endotel dan disertai pembentukan neointima karotis. Butirat dapat bermanfaat terhadap inflamasi vaskular atau aterosklerosis melalui penghambatan produksi $\mathrm{O}_{2}^{-}$dan pembentukan dan aktivasi inflamasom Nlrp3.

Diet sangat berperan dalam membentuk mikrobiota usus dan merupakan cara yang paling mudah dan menarik sebagai intervensi terapi. ${ }^{13}$ Konsumsi makanan dapat mengubah komposisi mikrobiota yang menyintesis SCFA baik di dalam kolon maupun usus halus distal. Selain itu, pengaturan makanan dapat memengaruhi sel epitel usus halus dan dapat dipergunakan untuk memodulasi sistem imun mukosa. ${ }^{20}$

Peran SCFA yaitu butirat telah dikenal juga sebagai anti-inflamasi dan antineoplasma. ${ }^{7,12,29}$ Butirat dapat bekerja sebagai kemoprevensi sekunder dengan cara memperlambat pertumbuhan dan mengaktivasi apoptosis pada sel kanker kolon; hal ini diduga melalui upregulasi traskripsional dari enzim detoksifikasi seperti glutation-Stransferase (GSTs). ${ }^{7}$

Hubungan mutualistik antara pejamu dan mikrobiota usus memberi pencerahan terhadap pentingnya komponen mikrobiota usus dan metabolitnya dalam mempertahankan homeostasis jaringan dan sistem imun. Dari berbagai metabolit yang dihasilkan tampaknya SCFA merupakan molekul pesinyal dalam usus dan jaringan perifer untuk menekan inflamasi dan memberikan respons proteksi langsung. ${ }^{13}$

Walaupun SCFA sebagai hasil fermentasi dan metabolisme mikrobiota usus belum dapat ditetapkan sebagai endpoint fisiologik namun telah diterima sebagai metabolit 
yang bermanfaat terhadap kesehatan. ${ }^{33}$ Dengan melihat fungsi proteksi terhadap penyakit saluran cerna dan saluran napas, maka SCFA dan diet dapat menjadi pendekatan terapeutik yang menjanjikan. Untuk itu diperlukan pemahaman yang mendalam mengenai mekanisme molekular dan selular yang mendasari kerja SCFA. ${ }^{13}$

\section{Simpulan}

SCFA merupakan produk akhir hasil fermentasi karbohidrat dan protein oleh mikrobiota usus. Jenis SCFA yang terutama didapatkan pada manusia ialah asetat, propionat, dan butirat. SCFA berfungsi antara lain mempertahankan homeostasis tubuh. memodulasi proses metabolism dan sistem imun, serta proteksi langsung terhadap patogen pada berbagai jaringan tubuh termasuk jaringan ekstraintestinal.

Walaupun efek fisiologik SCFA sangat menjanjikan namun pemanfaatannya dalam pengobatan masih sangat terbatas oleh karena adanya perbedaan fisiologik dan diet. Selain itu, yang turut menjadi tantangan ialah bagaimana memasok sejumlah SCFA yg cukup ke tempat target antara lain saluran cerna dan sistem sirkulasi.

\section{Konflik Kepentingan}

Penulis menyatakan tidak terdapat konflik kepentingan dalam studi ini.

\section{DAFTAR PUSTAKA}

1. Alvarez-Curto E, Milligan G. Metabolism meets immunity: The role of free fatty acid receptors in the immune system. Biochem Pharmacol. 2016;114:3-13.

2. Blüher M. Obesity: global epidemiology and pathogenesis. Nat Rev Endocrinol. 2019;15:288-98.

3. Meijer K, de Vos P, Priebe MG. Butyrate and other short chain fatty acids as modulators of immunity: what relevance for health? Curr Opin Clin Nutr Metab Care. 2010;13:715-21.

4. Saeedi P, Petersohn I, Salpea P, Malanda B, Karuranga S, Unwin N, et al. Global and regional diabetes prevalence estimates for 2019 and projections for 2030 and 2045: Results from the International Diabetes Federation Diabetes Atlas (9th ed). IDF Diabetes Atlas Committee, 2019. DOI: https://doi.org/ 10.1016/j.diabres.2019.107843

5. Alexander MR, Yang EH, Madhur MS. What is the global prevalence of hypertension (high blood pressure)? Updated: Feb 22, 2019. Available from: https://www. medscape.com/answers/241381-

7614/what-is-the-global-prevalence-ofhypertension-high-blood-pressure

6. Thorburn AN, McKenzie CI, Shen SJ, Stanley $\mathrm{D}$, Marcia L, et al. Evidence that asthma is a developmental origin disease influenced by maternal diet and bacterial metabolites. Nat Commun. 2015:1-11. Doi: $10.1038 /$ ncomms8320.

7. Canani RB, Di Costanzo M, Leone L, Pedata M, Meli R, Calignano A. Potential beneficial effects of butyrate in intestinal and extraintestinal diseases. WJG. 2011; 17(12):1519-28.

8. Liu H, Wang J, He T, Becker S, Zhang G, Li D, Ma X. Butyrate: a doubled-edged sword for health? Adv Nutr. 2018;9:21-9.

9. Baxter NT, Schmidt AW, Venkataraman A, Kim KS, Waldron C, Schmidt TM. Dynamics of human gut microbiota and short-chain fatty acids in response to dietary interventions with three fermentable fibers. MBio. 2019;10(1):1-11.

10. Gill PA, van Zelm MC, Muir JG, Gibson PR. Review article: short chain fatty acids as potential therapeutic agents in human gastrointestinal and inflammatory disorders. Aliment Pharmacol Ther. 2018; 48:15-34.

11. Feng W, Ao H, Peng Ch. Gut microbiota, short-chain fatty acids, and herbal medicines. Front Pharmacol. 2018; 9(1354):1-9.

12. Thursby E, Juge $N$. Introduction to the human gut microbiota. Biochem J. 2017; 474:1823-36.

13. Dang AT, Marsland BJ. Microbes, meta bolites, and the gut-lung axis. Mucosal Immunol. 2019;12:843-50.

14. Fujimura KE, Lynch SV. Microbiota in allergy and asthma and the emerging relation ship with the gut microbiome. Cell Host Microbe. 2015;17(5):592-602.

15. Lozupone CA, Stombaugh JI, Gordon JI, Jansson JK, Knight R. Diversity, stability and resilience of the human gut microbiota. Nature. 2012;489(7415): 220-30. 
16. Hugon P, Dufour JC, Colson P, Fournier PE, Sallah K, Raoult D. A comprehensive repertoire of prokaryotic species identified in human beings. Lancet Infect Dis. 2015;15:1211-19.

17. Li J, Jia H, Cai X, Zhong H, Feng Q, Sunagawa $A$, et al. An intergrated catalog of reference genes in human gut microbiome. Nat Biotechnol. 2014; 32:834-41.

18. McAleer JP, Kolls JK. Contributions of the intestinal microbiome in lung immunity. Eur J Immunol. 2018;48(1):39-49.

19. Ivashkin V, Zolnikova O, Potskherashvili N, Trukhmanov A, Kokina N, Dzhakhaya $\mathrm{N}$, et al. Metabolic activity of intestinal microflora in patients with bronchial asthma. Clin Pract. 2019;9(1126):18-22.

20. Goverse G, Molenaar R, Macia L, Tan J, Erkelens MN, Konijn T, et al. Dietderived short chain fatty acids stimulate intestinal epithelial cells to induce mucosal tolerogenic dendritic cells. J Immunol. 2017;198(5):2172-81.

21. Holscher HD. Dietary fiber and prebiotic and the gastrointestinal microbiota. Gut Microbes. 2017;8(2):172-84.

22. Bilotta AJ, Yingzi Cong. Gut microbiota metabolite regulation of host defenses at mucosal surfaces: implication in precision medicine. Precis Clin Med. 2019;2(2):110-9.

23. Postler TS, Ghosh S. Understanding the holobiont: how microbial metabolites affect human health and shape the immune system. Cell Metab. 2017; 26(1):110-30.

24. Cait A, Hughes MR, Antignano F, Cait J, Dimitriu PA, Maas KR, et al. Microbiome-driven allergic lung inflammation is ameliorated by short-chain fatty acids. Mucosal Immunol. 2018;11(3):785-94.

25. Yuan X, Wang L, Bhat OM, Lohner H, Li PL. Differential effects of short chain fatty acids on endothelial Nlrep3 inflam- masome activation and neointima formation: Antioxidant action of butyrate. Redox Biol. 2018;16:21-31.

26. Trompette A, Gollwitzer ES, Yadava K, Sichelstiel AK, Sprenger N, Ngom-Bru $\mathrm{C}$, et al. Gut microbiota metabolism of dietary fiber influences allergic airway disease and hematopoiesis. Nat Med. 2014:1-7. Doi:10.1038/nm.3444.

27. Theiler A, Barnthaler T, Platzer W, Richtig G, Peinhaupt M, Rittchen S, et al. Butyrate ameliorates allergic airway inflamemation by limiting eosinophil trafficking and survival. J Allergy Clin Immunol. 2019;144(3):764-75.

28. Anand S, Mande SS. Diet, microbiota and gutlung connection. Front Microbiol. 2018;9:2147.

29. Lewis SJ, Heatlon KW. Increasing butyrate concentration in the distal colon by accelerating intestinal transit. Gut. 199;41:245-51.

30. Hatayama H, Iwashita J, Kuwajima A, Abe T. The short chain fatty acid, butyrate, stimulates MUC2 mucin production in the human colon cancer cell line, LS174T. Biochem Biophys Res Commun. 2007;356:599-603.

31. Jung T, Park JH, Jeon W-M, Han K-S. Butyrate modulates bacterial adherence on LS174T human colorectal cells by stimulating mucin secretion and MAPK signaling pathway. Nutr Res Pract. 2015;9:343-9.

32. Alexander C, Swanson KS, Fahey GC Jr, Garleb KA. Perspective: Physiologic importance of short-chain fatty acids from nondigestible carbohydrate fermentation. Adv Nutr. 2019;10:576-89.

33. Wangko WS. Hubungan short chain fatty acid butirat dengan tes control asma, immunoglobulin $\mathrm{E}$ total, dan arus puncak ekspirasi pada asma bronkial dewasa dan perbedaannya dengan subyek normal [Tesis]. Manado, Universitas Sam Ratulangi; 2020. 